\title{
HUBUNGAN GAYA KEPEMIMPINAN OTOKRATIS DENGAN KOMITMEN ORGANISASIONAL KARYAWAN PADA PT MITRA MEGAH SENTOSA
}

\author{
Ega Prianih dan Nancy Yusnita \\ Fakultas Ekonomi Universitas Pakuan \\ E-mail: nancyyusnita@yahoo.co.id
}

\begin{abstract}
ABSTRAK
Tujuan penelitian ini untuk mengetahui dan menganalisis hubungan antara gaya kepemimpinan otokratis dengan komitmen organisasional. Data diperoleh dengan menyebarkan kuesioner kepada 43 orang, yang merupakan populasi karyawan dari perusahaan yang diteliti. Hasil penelitian menunjukkan hubungan yang sangat kuat $(r=0,890)$ antara gaya kepemimpinan otokratis dengan komitmen organisasional karyawan. Hasil uji hipotesis dengan $t$ hitung lebih besar dari $t$ tabel $(12,657>2,019)$ menunjukkan hubungan positif antara gaya kepemimpinan otokratis dengan komitmen organisasional karyawan. Koefisien determinasi sebesar 0,792 menunjukkan bahwa gaya kepemimpinan otokratis memiliki peranan sebesar 0,792 terhadap komitmen organisasional karyawan.
\end{abstract}

Kata Kunci: Gaya Kepemimpinan Otokratis, Komitmen Organisasional Karyawan

\section{PENDAHULUAN}

Setiap organisasi mengharapkan adanya komitmen organisasi yang kuat dari setiap karyawan untuk dapat mencapai tujuan perusahaan. Komitmen kuat menjadi urgensi yang tidak mungkin ditawar lagi untuk kelangsungan hidup organisasi serta pengembangan organisasi. Selain berpengaruh terhadap perusahaan, komitmen individu yang kuat dalam bekerja akan membantu untuk menunjukkan kinerja terbaiknya yang pada akhirya berdampak pada karir karyawan tersebut. Sehingga komitmen organisasional menjadi faktor strategis dalam kepentingan organisasi dan karyawan.

Sebuah perusahaan membutuhkan figur atau sosok kepemimpinan yang mampu memotivasi, mengkoordinasi orang-orang atau karyawan ke dalam kelompok kerja serta mengintegrasi mereka ke dalam situasi atau iklim kerja yang solid dan harmonis guna mencapai tujuan bersama. Oleh karena itu gaya kepemimpinan menjadi faktor penting yang menentukan suksesnya organisasi untuk mencapai tujuannya. Menurut Kartono (2008:34) gaya kepemimpinan adalah sifat, kebiasaan, tempramen, watak dan kepribadian yang membedakan seorang pemimpin dalam berinteraksi dengan orang lain. Sedangkan kepemimpinan otokratis adalah gaya kepemimpinan yang menggunakan metode pendekatan kekuasaan dalam mencapai keputusan dan pengembangan strukturnya, sehingga kekuasaanlah yang paling diuntungkan dalam organisasi (Rivai, 2013:42).

Di PT Mitra Megah Sentosa sebagai tempat dilakukannya penelitian terdapat fenomena banyaknya karyawan yang memutuskan mengundurkan diri dengan berbagai macam alasan seperti gaji rendah, lingkungan kerja tidak nyaman dan kepemimpinan atasan yang kurang baik. Hal ini menunjukkan bahwa di PT Mitra Megah Sentosa komitmen organisasional karyawan yang bekerja sangat lemah. Peningkatan karyawan yang resign (mengundurkan diri) membuat PT Mitra Megah Sentosa mengalami tingkat turnover karyawan yang cukup tinggi, absensi, serta keterlambatan kerja. Bahkan dari data yang diperoleh, di PT Mitra Megah Sentosa dapat diidentifikasi figur pimpinan merupakan sosok yang sangat

JIMFE (Jurnal Ilmiah Manajemen Fakultas Ekonomi)

Volume 3 No. 2 Tahun 2017, Hal. 49-59 
berpengaruh terhadap karyawan. Hal ini dapat dilihat dari hasil kuesioner mengenai gaya kepemimpinan dari para karyawan sebagai berikut.

Tabel 1.

Data Hasil Kuesioner Ukuran Terhadap Gaya Kepemimpinan Otokratis

Pada PT Mitra Megah Sentosa

\begin{tabular}{|c|l|c|c|}
\hline \multirow{2}{*}{ No. } & \multicolumn{1}{|c|}{ Pertanyaan } & \multicolumn{2}{c|}{ Pendapat } \\
\cline { 3 - 4 } & \multicolumn{1}{|c|}{ S } & TS \\
\hline 1 & Pimpinan saya memberi perintah yang harus dipatuhi & $86 \%$ & $14 \%$ \\
\hline 2 & Kebijakan ditentukan tanpa konsultasi dengan bawahan & $67 \%$ & $33 \%$ \\
\hline 3 & $\begin{array}{l}\text { Pimpinan saya meminta agar karyawan mengikuti aturan- } \\
\text { aturan yang ada }\end{array}$ & $93 \%$ & $7 \%$ \\
\hline 4 & Pimpinan saya tidak menerima masukan dari bawahannya & $73 \%$ & $27 \%$ \\
\hline 5 & $\begin{array}{l}\text { Pimpinan saya paham apa yang diharapkan dari pegawai } \\
\text { pada saat melakukan penugasan }\end{array}$ & $73 \%$ & $27 \%$ \\
\hline 6 & $\begin{array}{l}\text { Pimpinan saya menganggap organisasi sebagai milik } \\
\text { pribadi }\end{array}$ & $60 \%$ & $40 \%$ \\
\hline 7 & $\begin{array}{l}\text { Pimpinan saya tidak menerima alasan yang dikemukakan } \\
\text { bawahan untuk hal apapun }\end{array}$ & $67 \%$ & $33 \%$ \\
\hline
\end{tabular}

Dari Tabel 1 di atas yang merupakan hasil jawaban para responden, menunjukkan variable $X$ (gaya kepemimpinan otokratis) yang ada di PT Mitra Megah Sentosa cenderung memiliki gaya kepemimpinan otokratis.

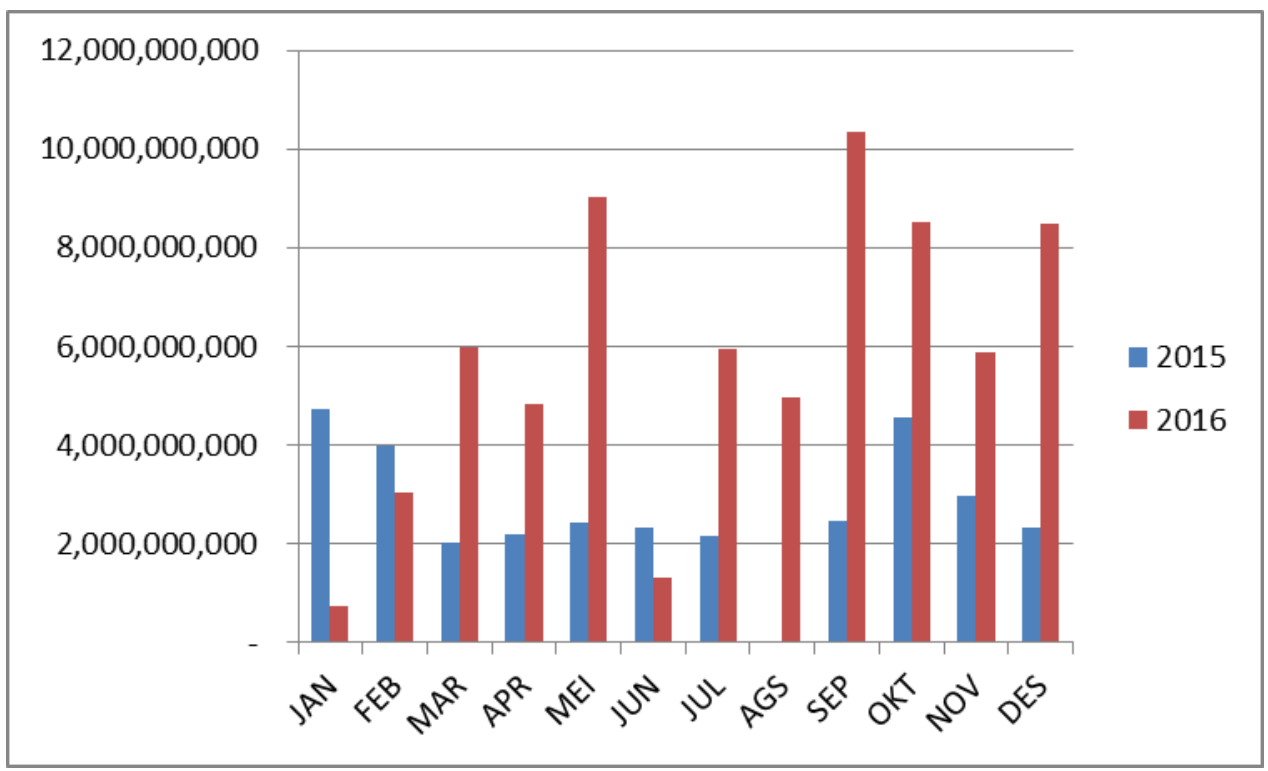

Gambar 1.

Data Penjualan 2015-2016

PT Mitra Megah Sentosa 
Kondisi ini berimbas pada penjualan PT Mitra Megah Sentosa. Dari data di atas menunjukkan bahwa penjualan perusahaan di tahun 2015 dan 2016 mengalami fluktuasi yang tajam. Komitmen kerja karyawan yang rendah memberikan hasil pekerjaan yang kurang baik sehingga penjualan perusahaan pun mengalami ketidakstabilan.

Tabel 2.

Data Turn Over Karyawan

PT Mitra Megah Sentosa Tahun 2016

\begin{tabular}{|l|c|c|c|c|c|c|c|c|c|c|c|c|c|}
\hline & \multicolumn{10}{|c|}{ Tahun } & \multirow{2}{*}{ Jml } \\
\cline { 1 - 16 } & Jan & Feb & Mar & Apr & Mei & Jun & Jul & Agust & Sep & Okt & Nop & Des & \\
\hline Marketing & 1 & - & - & - & 1 & - & - & - & - & - & 1 & - & 3 \\
\hline Tehnik & - & - & - & - & - & - & - & 1 & - & - & - & - & 1 \\
\hline Estate & - & - & - & - & - & - & 1 & - & - & - & 1 & - & 2 \\
\hline
\end{tabular}

Tabel 2 menunjukkan bahwa tingkat perputaran karyawan di PT Mitra Megah Sentosa untuk setiap divisi mengalami turn over yang tinggi. Hal ini menyebabkan kondisi yang kurang baik untuk perusahaan. Bahkan komitmen karyawan terhadap perusahaan di tahun 2016 dapat dikatakan berada dalam kondisi yang memprihatinkan yang terlihat dari tingkat absensi karyawan yang tinggi (Tabel 3) dan tingkat keterlambatan masuk kerja dari 43 karyawan yang semakin sering terjadi sepanjang tahun 2016 (Tabel 4).

Tabel 3.

Data Absensi Karyawan

PT Mitra Megah Sentosa Tahun 2016

\begin{tabular}{|c|c|c|c|c|c|c|c|c|c|c|c|c|c|c|c|}
\hline \multirow{2}{*}{ Kategori } & \multirow{2}{*}{$\begin{array}{c}\text { Jumlah } \\
\text { Karyawan }\end{array}$} & \multicolumn{12}{|c|}{ Tahun 2016} & \multirow{2}{*}{$\mathrm{Jml}$} & \multirow{2}{*}{$\%$} \\
\hline & & Jan & Feb & Mar & Apr & Mei & Jun & Jul & Agus & Sep & Okt & Nop & Des & & \\
\hline Sakit & 43 & 2 & 1 & 2 & 0 & 2 & 2 & 0 & 1 & 1 & 1 & 2 & 2 & 16 & $37 \%$ \\
\hline Izin & 43 & 0 & 1 & 1 & 1 & 0 & 1 & 1 & 0 & 1 & 2 & 1 & 0 & 9 & $21 \%$ \\
\hline Alfa & 43 & 1 & 0 & 1 & 0 & 1 & 1 & 0 & 1 & 0 & 2 & 1 & 0 & 8 & $19 \%$ \\
\hline
\end{tabular}

Tabel 4.

Data Keterlambatan Masuk Kerja Karyawan

PT Mitra Megah Sentosa Tahun 2016

\begin{tabular}{|l|c|c|c|c|}
\hline Bulan & $\begin{array}{c}\text { Jumlah } \\
\text { Karyawan }\end{array}$ & $\begin{array}{c}\text { Jumlah Hari } \\
\text { Kerja (JHK) }\end{array}$ & $\begin{array}{c}\text { Jumlah Keterlambatan } \\
\text { Masuk Kerja (Hari) }\end{array}$ & $\%$ \\
\hline Jan & 43 & 24 & 13 & 1,26 \\
\hline Feb & 43 & 24 & 18 & 1,74 \\
\hline Mar & 43 & 25 & 17 & 1,58 \\
\hline Apr & 43 & 26 & 19 & 1,70 \\
\hline Mei & 43 & 24 & 16 & 1,55 \\
\hline Jun & 43 & 26 & 20 & 1,79 \\
\hline Jul & 43 & 20 & 17 & 1,98 \\
\hline Agust & 43 & 26 & 13 & 1,16 \\
\hline Sep & 43 & 25 & 18 & 1,67 \\
\hline Okt & 43 & 26 & 19 & 1,70 \\
\hline Nop & 43 & 26 & 21 & 1,88 \\
\hline Des & 43 & 25 & 24 & 2,23 \\
\hline
\end{tabular}

JIMFE (Jurnal Ilmiah Manajemen Fakultas Ekonomi)

Volume 3 No. 2 Tahun 2017, Hal. 49-59 
Berdasarkan kondisi yang terjadi di PT Mitra Megah Sentosa, penelitian ini dilakukan untuk mengetahui hubungan gaya kepemimpinan otokratis yang diterapkan di perusahaan dan tingkat komitmen organisasional karyawan.

\section{KAJIAN LITERATUR}

Gaya kepemimpinan otokratis mendeskripsikan pemimpin yang cenderung memusatkan kekuasaan kepada dirinya sendiri, mendikte bagaimana tugas harus diselesaikan, membuat keputusan secara sepihak, dan meminimalisasi partisipasi karyawan. (Robbins dan Coulter, 2002:460). Menurut Rivai (2014:42) menyatakan bahwa kepemimpinan otokratis adalah gaya kepemimpinanyang menggunakan metode pendekatan kekuasaan dalam mencapai keputusan dan pengembangan strukturnya, sehingga kekuasaanlah yang paling diuntungkan dalam organisasi. Tipe kepemimpinan otokratis menganggap bahwa kepemimpinan adalah hak pribadinya (pemimpin), sehingga ia tidak perlu berkonsultasi dengan orang lain dan tidak boleh ada orang lain yang turut campur. Seorang pemimpin otokratik akan menunjukan sikap yang menonjolkan keakuannya, dan selalu mengabaikan peranan bawahan dalam proses pengambilan keputusan, tidak mau menerima saran dan pandangan bawahannya. (Sutikno, 2014:35)

\section{METODE PENELITIAN}

Jenis penelitian menggunakan
penelitian korelasional yaitu untuk
mengetahui seberapa erat hubungan antara
variabel gaya kepemimpinan otokratis
dengan variabel komitmen organisasional
karyawan. Variabel gaya kepemimpinan
otokratis merupakan variabel independen
sedangkan variabel dependen diwakili oleh
komitmen organisasional karyawan.
Unit analisis dalam penelitian ini
adalah populasi dari karyawan PT Mitra
Megah Sentosa. Perusahaan ini memiliki

karyawan sebanyak 43 orang yang semuanya menjadi responden. PT Mitra Megah Sentosa berlokasi di Jln. Raya Bogor Km. 49 merupakan sebuah badan usaha yang bergerak dalam bidang usaha properti.

\section{Metode Pengumpulan Data}

Prosedur pengambilan data dilakukan dengan langkah-langkah sebagai berikut:

1. Wawancara

Wawancara digunakan untuk pengumpulan data sebagai studi pendahuluan dalam menemukan permasalahan yang ada di PT Mitra Megah Sentosa.

2. Observasi

Observasi terhadap kegiatan perusahaan sebagai subjek penelitian, baik secara langsung maupun tidak langsung untuk menunjang pengumpulan data serta mempelajari berbagai berkas yang ada seperti peraturan, prosedur, dan kebijakan yang ditetapkan perusahaan sebagai objek penelitian.

3. Dokumentasi

Teknik dokumentasi yang dimaksud dalam penelitian ini adalah mencatat, mengutip dan melampirkan data baik berupa dokumen perusahaan, teori-teori pendukung dan hal lain yang mendukung penelitian.

4. Kuesioner

Teknik pengumpulan data ini memuat semua daftar pertanyaan yang diajukan pada para manajemen perusahaan dan karyawan sebagai responden. Dalam penelitian ini, kuesioner diberikan secara langsung kepada karyawan PT Mitra Megah Sentosa yang telah ditetapkan sebagai sampel. Kemudian pertanyaan dalam kuesioner tersebut akan diukur dengan menggunakan skala Likert. Pertanyaan dalam kuesioner berkaitan dengan variabel penelitian yaitu gaya kepemimpinan otokratis (X) dan komitmen organisasional $(\mathrm{Y})$. Jawaban setiap item instrumen yang 
menggunakan skala Likert mempunyai gradasi dari sangat positif sampai sangat negatif. Dalam hal ini pilihan jawaban yang digunakan adalah sebagai berikut:

Tabel 5.

Bobot nilai jawaban skala likert

\begin{tabular}{|l|c|}
\hline \multicolumn{1}{|c|}{ Jawaban } & Bobot \\
\hline Sangat Setuju (SS) & 5 \\
\hline Setuju (S) & 4 \\
\hline Ragu-ragu (R) & 3 \\
\hline Tidak Setuju (TS) & 2 \\
\hline Sangat Tidak Setuju (STS) & 1 \\
\hline
\end{tabular}

Sumber: Sugiyono $(2014,169)$

\section{Kalibrasi Instrumen Penelitian}

1. Uji Validitas

Sebelum instrumen/alat ukur digunakan untuk mengumpulkan data penelitian, maka perlu dilakukan uji coba kuesioner untuk mendapatkan validitas dan reabilitas alat ukur tersebut. Uji validitas berguna untuk mengetahui apakah alat tersebut valid. Valid artinya ketepatan mengukur sebuah variabel yang akan diukur. Jika ada butir pertanyaan kuesioner yang tidak valid maka butir pertanyaan kuesioner tersebut dapat diganti atau dibuang.
Menurut Ghozali $(2011,52)$ uji validitas digunakan untuk mengetahui sah atau valid tidaknya suatu kuesioner. Suatu kuesioner dikatakan valid jika pertanyaan pada kuesioner mampu untuk mengungkapkan sesuatu yang akan diukur oleh kuesioner tersebut. Uji signifikasi dilakukan dengan membandingkan nilai $r_{\text {hitung }}$ dengan $r_{\text {tabel, }}$ jika $r_{\text {hitung }}>r_{\text {tabel }}$ dan bernilai positif, maka variabel tersebut valid. Sedangkan jika $r_{\text {hitung }}<r_{\text {tabel, }}$ maka variabel tersebut tidak valid.

Rumus yang digunakan untuk uji validitas adalah rumus korelasi product moment sebagai berikut:

$$
\mathbf{r}_{\mathrm{xy}}=\frac{n \cdot \Sigma x y \cdot \Sigma x \Sigma y}{\sqrt{n \Sigma x^{2}-(\Sigma x)^{2}} \sqrt{n \Sigma y^{2}-(\Sigma y)^{2}}}
$$

Sugiyono (2011:183)

\section{Keterangan:}

$R x y=$ Menunjukan indeks korelasi antara dua variabel yang dikorelasikan

$\mathrm{R}=$ Koefisien validitas item yang dicari, dua variabel yang dikorelasikan

$X=$ Skor untuk pernyataan yang dipilih

$Y=$ Skor total yang diperoleh dari seluruh item

$\sum \mathrm{x}=$ Jumlah skor dalam distribusi $\mathrm{X}$

$\sum y=$ Jumlah skor dalam distribusi $Y$

$\sum \mathrm{X}^{2}=$ Jumlah kuadrat dalam skor distribusi $\mathrm{X}$

$\sum y^{2}=$ Jumlah kuadrat dalam skor distribusi $Y$

$\mathrm{N}$ = Banyaknya responden 
Dengan $\mathrm{n}=30$ maka dasar pengambilan keputusan valid atau tidaknya adalah sebagai berikut:

Jika $r \geq 0,361$ maka item pernyataan tersebut valid.

Jika $r<0,361$ maka item pernyataan tersebut tidak valid.

\section{Uji Validitas}

Uji Validitas Gaya Kepemimpinan Otokratis Uji validitas dari variabel gaya kepemimpinan otokratis menunjukkan hasil uji validitas dengan menggunakan program SPSS 20 dari 18 item pertanyaan, 3 item dinyatakan tidak valid karena $r_{\text {hitung }}$ $<r_{\text {tabel. }}$ Sedangkan 15 item lainnya dinyatakan valid sehingga dapat digunakan untuk pembahasan selanjutnya.

Uji Validitas Komitmen Organisasional Karyawan

Uji validitas dari variabel komitmen organisasional karyawan dapat dilihat bahwa hasil uji validitas dengan menggunakan program SPSS 20 tersebut dari 25 item pertanyaan, 4 item dinyatakan tidak valid karena $r_{\text {hitung }}<r_{\text {tabel }}$. Sedangkan 21 item lainnya dinyatakan valid sehingga dapat digunakan untuk pembahasan selanjutnya.

2. Uji Reliabilitas

Uji reliabilitas (tingkat kepercayaan) data yang tinggi terjadi jika fakta yang telah dikumpulkan tidak berubah apabila diadakan pengamatan ulang. Reliabilitas merupakan suatu istilah yang digunakan untuk menunjukkan sejauh mana suatu hasil pengukuran relatif konsisten, pengukuran relatif konsisten apabila pengukuran diulangi dua kali atau lebih. Menguji reliabilitas dapat diukur dengan menggunakan rumus :

Alpha Cronbach

$r_{i}=\frac{k}{(k-1)}\left\{1-\frac{\sum s_{i}{ }^{2}}{s_{t}{ }^{2}}\right\}$

Keterangan :

$r_{i}=$ Nilai reliabilitas

$k=$ Nilai koefisien korelasi antara

belahan pertama dan kedua

$\sum s_{i}{ }^{2}=$ Mean kuadrat kesalahan

$S_{t 2}=$ Varians total

(Harbani Pasolong, 2012,178)

Uji Reliabilitas Item Gaya Kepemimpinan Otokratis

Tabel 6.

Reliability Statistics

\begin{tabular}{|c|r|}
\hline $\begin{array}{c}\text { Cronbach's } \\
\text { Alpha }\end{array}$ & N of Items \\
\hline .845 & 18 \\
\hline
\end{tabular}

Sebagaimana hasil yang dapat dilihat pada Tabel 6, Reliability Statistics menunjukkan bahwa Cronbach Alpha 0,845 , hal ini membuktikan bahwa instrumen reliabel (dapat diandalkan).
Uji Reliabilitas Item Komitmen Organisasional Karyawan 
Tabel 7.

Reliability Statistics Item Kinerja

Karyawan

\begin{tabular}{|r|r|}
\hline Cronbach's Alpha & N of Items \\
\hline .892 & 25 \\
\hline
\end{tabular}

Sebagaimana hasil yang dapat dilihat pada Tabel 7 Reliability Statistics menunjukkan bahwa Cronbach Alpha 0,892, hal ini membuktikan bahwa instrumen reliabel (dapat diandalkan).

\section{HASIL PENELITIAN}

Berdasarkan input data di atas dapat disimpulkan secara deskriptif distribusi frekuensi menggunakan SPSS 20 sebagai berikut:

Tabel 8.

Gaya Kepemimpinan Otokratis

\begin{tabular}{|r|r|r|r|r|}
\hline & \multicolumn{1}{|l|}{ Frequency } & \multicolumn{1}{c|}{ Percent } & Valid Percent & Cumulative Percent \\
\hline Valid 60.00 & 1 & 2.3 & 2.3 & 2.3 \\
\hline 61.00 & 1 & 2.3 & 2.3 & 4.7 \\
\hline 63.00 & 3 & 7.0 & 7.0 & 11.6 \\
\hline 64.00 & 1 & 2.3 & 2.3 & 14.0 \\
\hline 65.00 & 4 & 9.3 & 9.3 & 23.3 \\
\hline 66.00 & 4 & 9.3 & 9.3 & 32.6 \\
\hline 67.00 & 4 & 9.3 & 9.3 & 41.9 \\
\hline 68.00 & 4 & 9.3 & 9.3 & 51.2 \\
\hline 69.00 & 5 & 11.6 & 11.6 & 62.8 \\
\hline 70.00 & 8 & 18.6 & 18.6 & 81.4 \\
\hline 71.00 & 4 & 9.3 & 9.3 & 90.7 \\
\hline 72.00 & 2 & 4.7 & 4.7 & 95.3 \\
\hline 74.00 & 2 & 4.7 & 4.7 & 100.0 \\
\hline total & 43 & 100.0 & 100.0 & \\
\hline & & & & \\
\hline
\end{tabular}

Tabel 9.

Distribusi Frekuensi Gaya Kepemimpinan Otokratis

\begin{tabular}{|c|c|}
\hline $\mathrm{N}$ & 43 \\
\hline \multicolumn{2}{|c|}{ Missing } \\
\hline Mean & 67.8837 \\
\hline Median & 68.0000 \\
\hline Mode & 70.00 \\
\hline Range & 14.00 \\
\hline Minimum & 60.00 \\
\hline Maximum & 74.00 \\
\hline Sum & 2919.00 \\
\hline
\end{tabular}

Hasil menunjukkan bahwa rata-rata berdasarkan pertanyaan yang dijawab empiris gaya kepemimpinan otokratis responden adalah 67,88 . Untuk mengetahui

JIMFE (Jurnal Ilmiah Manajemen Fakultas Ekonomi)

Volume 3 No. 2 Tahun 2017, Hal. 49-59 
gaya kepemimpinan otokratis yang ada pada PT Mitra Megah Sentosa, hasil dari rata-rata empiris dibandingkan dengan rata-rata teoritis sebagai berikut:

Skor Teoritis $(X)=\frac{1(15)+5(15)}{2}=45$
Berdasarkan hasil tersebut skor ratarata empiris sebesar 67,88 dan skor rata-rata teoritis sebesar 45, sehingga skor rata-rata empiris lebih besar daripada skor rata-rata teoritis. Oleh karena itu dapat dikatakan gaya kepemimpinan otokratis pada PT Mitra Megah Sentosa relatif baik.

Tabel 10.

Distribusi Frekuensi Komitmen Organisasional Karyawan

\begin{tabular}{|c|c|c|}
\hline $\mathrm{N}$ & Valid & 43 \\
\hline & Missing & 0 \\
\hline Mean & & 97.2791 \\
\hline Median & & 99.0000 \\
\hline Mode & & 102.00 \\
\hline Range & & 17.00 \\
\hline Minimum & & 85.00 \\
\hline Maximum & & 102.00 \\
\hline Sum & & 4183.00 \\
\hline
\end{tabular}

Hasil olah data menunjukkan rata-rata empiris komitmen organisasional karyawan berdasarkan pertanyaan yang dijawab responden adalah 97,28. Untuk mengetahui komitmen organisasional karyawan yang ada pada PT Mitra Megah Sentosa, maka hasil dari rata-rata empiris dibandingkan dengan rata-rata teoritis sebagai berikut:

$$
\text { Skor Teoritik }(X)=\frac{1(21)+5(21)}{2}=63
$$

Hasil tersebut menunjukkan skor ratarata empiris 97,28 dan skor rata-rata teoritis sebesar 63 sehingga skor rata-rata empiris lebih besar dari pada skor rata-rata teoritis. Oleh karena itu dapat disimpulkan komitmen organisasional karyawan pada PT Mitra Megah Sentosa relatif baik.

\section{Hubungan Gaya Kepemimpinan Otokratis Dengan Komitmen Organisasional Karyawan pada PT Mitra Megah Sentosa Analisis Koefisien Korelasi}

Untuk mengetahui keeratan hubungan antara dua variabel yaitu variabel gaya kepemimpinan otokratis dan variable komitmen organisasional karyawan dapat dilihat pada tabel Correlations dibawah ini : 
Tabel 11.

Correlation

\begin{tabular}{|c|c|c|c|}
\hline & & $\begin{array}{c}\text { Gaya } \\
\text { Kepemimpinan } \\
\text { Otokratis }\end{array}$ & $\begin{array}{c}\text { Komitmen } \\
\text { Organisasional } \\
\text { Karyawan }\end{array}$ \\
\hline \multirow[t]{3}{*}{$\begin{array}{l}\text { Gaya Kepemimpinan } \\
\text { Otokratis }\end{array}$} & Pearson Correlation & 1 & .890 \\
\hline & Sig. (1-tailed) & & .000 \\
\hline & $\mathrm{N}$ & 43 & 43 \\
\hline \multirow[t]{3}{*}{$\begin{array}{l}\text { Komitmen Organisasional } \\
\text { Karyawan }\end{array}$} & Pearson Correlation & .890 & 1 \\
\hline & Sig. (1-tailed) & .000 & \\
\hline & $\mathrm{N}$ & 43 & 43 \\
\hline
\end{tabular}

** Correlation is significant at the 0.01 level (1-tailed)

Berdasarkan hasil perhitungan dengan program SPSS di atas, maka dapat diketahui bahwa besarnya koefisien korelasi dari pearson product moment adalah 0,890 .
Selanjutnya untuk mengetahui bagaimana penafsiran terhadap koefisien korelasi maka diuji dengan nilai interval koefisien korelasi di bawah ini:

Tabel 12.

Nilai Interval Koefisien

\begin{tabular}{|c|c|l|}
\hline Interval Nilai & Nilai Pearson Product Moment & \multicolumn{1}{|c|}{ Tingkat Hubungan } \\
\hline $0.80-1.000$ & 0.890 & Sangat Kuat \\
\hline $0.60-0.799$ & & Kuat \\
\hline $0.40-0.599$ & & Cukup Kuat \\
\hline $0.20-0.399$ & & Rendah \\
\hline $0.00-0.199$ & & Sangat Rendah \\
\hline
\end{tabular}

Berdasarkan tabel nilai interval koefisien di atas, dapat dilihat bahwa gaya kepemimpinan otokratis mempunyai hubungan yang sangat kuat dengan komitmen organisasional karyawan.

\section{Analisis Koefisien Determinasi}

Seberapa besar gaya kepemimpinan otokratis dapat mempengaruhi turun naiknya komitmen organisasional karyawan dapat dilihat pada kolom $R$ Square dibawah ini :

$$
\begin{aligned}
\text { KD } & =r^{2} \times 100 \% \\
& =0,890^{2} \times 100 \% \\
& =0,7921 \times 100 \% \\
& =79,21 \%
\end{aligned}
$$

Hasil dari perhitungan analisis koefisien determinasi menunjukkan bahwa gaya kepemimpinan otokratis berkontribusi atau memberikan peranan terhadap komitmen organisasional karyawan sebesar $79,21 \%$, sedangkan sisanya sebesar $20,79 \%$ di jelaskan oleh faktor lain di luar komitmen organisasional yang tidak diteliti pada penelitian ini.

Uji Hipotesis

Hubungan nyata atau tidak antara gaya kepemimpinan otokratis dengan komitmen organisasional karyawan dapat diuji dengan melakukan uji hipotesis koefisien korelasi sebagai berikut:

a. Hipotesis Statistik

Ho: $\rho \leq 0$, tidak ada hubungan yang positif dan nyata antara gaya kepemimpinan otokratis

JIMFE (Jurnal Ilmiah Manajemen Fakultas Ekonomi)

Volume 3 No. 2 Tahun 2017, Hal. 49-59 


\section{dengan komitmen organisasional karyawan.}

$\mathrm{H}_{1}: \quad \rho>0$, terdapat hubungan positif dan nyata antara gaya kepemimpinan otokratis dengan komitmen organisasional karyawan.

b. Mencari tabel

Untuk mencari $t_{\text {tabel }}$ maka digunakan taraf nyata $5 \%(\alpha=5 \%)$ dan derajat kebebasan (df) n-2 atau 43-2=41. Hasil yang diperoleh adalah $t_{\text {tabel }}=$ 2,019.

c. Mencari $t_{\text {hitung }}$ dengan rumus:

$$
\begin{aligned}
t_{\text {hitung }} & =\frac{r \sqrt{n-2}}{\sqrt{1-r^{2}}} \\
& =\frac{0,890 \sqrt{43-2}}{\sqrt{1-0,890^{2}}} \\
& =0,890 \frac{\sqrt{41}}{\sqrt{0,2079}} \\
& =0,890 \times 14,22=12,657
\end{aligned}
$$

Berdasarkan hasil perhitungan di atas, diketahui bahwa nilai $t_{\text {hitung }}(=12,657)>t_{\text {tabel }}$ $(=2,019)$ sehingga Ho ditolak dan $\mathrm{H}_{1}$ diterima, artinya terdapat hubungan nyata dan positif antara gaya kepemimpinan otokratis dengan komitmen organisasional karyawan.

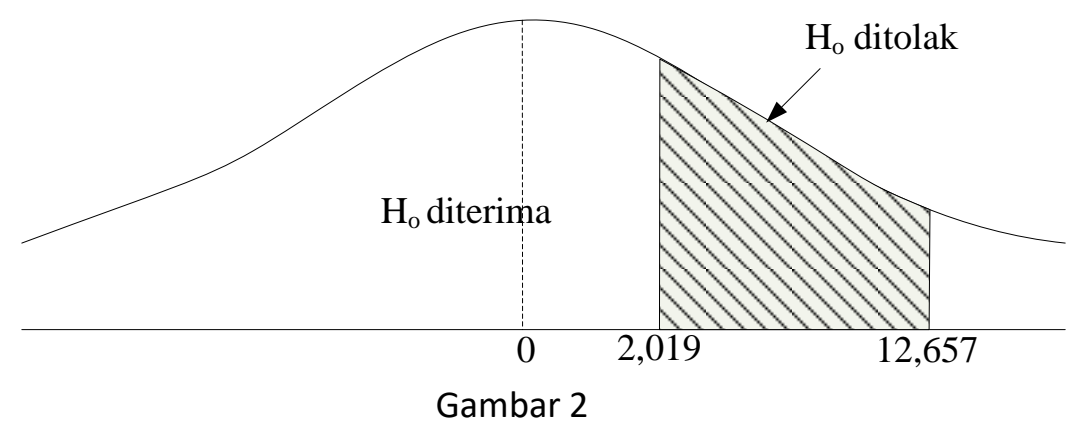

Daerah Penerimaan Hipotesis antara Gaya Kepemimpinan Otokratis dengan Komitmen Organisasional Karyawan

\section{PENUTUP}

Korelasi gaya kepemimpinan otokratis dan komitmen organisasional karyawan pada PT Mitra Megah Sentosa menunjukkan hubungan yang sangat kuat dengan nilai $r=$ 0,890 . Sementara hasil perhitungan analisis koefisien determinasi menunjukan bahwa gaya kepemimpinan otokratis dapat memengaruhi naik turunnya komitmen organisasional karyawan pada PT Mitra Megah Sentosa yaitu ditunjukkan dengan nilai koefisien determinasi sebesar $79,21 \%$, meski sisanya sebesar $20,79 \%$ dipengaruhi oleh faktor lain. Oleh karena itu dapat disimpulkan bahwa lemahnya komitmen organisasional karyawan PT Mitra Megah Sentosa dipengaruhi oleh gaya kepemimpinan otokratis. Dibuktikan dengan hasil uji hipotesis $t_{\text {hitung }}>t_{\text {tabel }}(12,657>2,019)$ yaitu adanya hubungan positif antara gaya kepemimpinan otokratis dengan komitmen organisasional karyawan pada PT Mitra Megah Sentosa.

\section{DAFTAR PUSTAKA}

Ghozali, Imam. 2011. "Aplikasi Analisis Multivariate Dengan Program SPSS". Semarang: Badan Penerbit Universitas Diponegoro.
Kartini,Kartono.2003. Pemimpin dan Kepemimpinan, Jakarta: Raja Grafindo Persada

Kartini, Kartono.2008. Pemimpin dan Kepemimpinan, Jakarta: Raja Grafindo Persada 
Pasolong, Harbani. 2012. Metode Penelitian Administrasi Publik. Bandung: Alfabeta.

Rivai, Veithzal, 2013. Manajemen Sumber daya Manusia Untuk Perusahaan Dari Teori Ke Praktek, Penerbit PT Raja Grafindo Persada, Jakarta.

Rivai, Veithzal, 2011. Manajemen Sumber daya Manusia Untuk Perusahaan Dari Teori Ke Praktek, Penerbit PT Raja Grafindo Persada, Jakarta.
Robbins, Stephen $\mathrm{P}$, and Coulter, Mary. (2002). Management, 7th edition. Prentice Hall, Inc., New Jersey.

Robbins, Stephen P, dan Judge, Kevin. 2007. Perilaku Organisasi, edisi dua belas. Jakarta: Salemba empat

Sugiyono 2011. Metode penelitian kuntitatif kualitatif dan R\&D. Alfabeta.

Sugiyono. 2014. Metode Penelitian Kuantitatif. Bandung: Alfabeta.

Sutikno, sobry M. 2014 Pemimpin Dan Gaya Kepemimpinan, Edisi Pertama. Lombok: Holistica. 